\title{
A comparison of web use in marketing by local government in the United States and Australia
}

Received (in revised form): 23rd July, 2007

\section{Stewart Adam}

is Associate Professor in Electronic Marketing, Faculty of Business and Law, Deakin University. His PhD focussed on the link between web use and organizational performance. His research interests may be viewed at www.stewartadam.com.

\section{Michael D. Featherstone}

is Assistant Professor in Information Management, College of Commerce and Business Administration, Jacksonville State University. His DBA focussed on identification of new business models and generating link popularity on the web.

Keywords marketing readiness of websites indicator, online marketing communication, online marketing channels, online relationship management, local government, county government

Abstract The study reported in this paper examines local government use of the web in marketing in Australia and the United States. An audit of local government websites is undertaken using a content analysis tool developed through academic and commercial use - the Marketing Readiness of Website Indicator (MRWI). By examining three elements of online marketing in this context, the authors identify similarly sophisticated use by local government in one Australian state (Victoria) and county government in the most populous state in the United States (California). The hypothesised more highly sophisticated web use by United States local government relative to Australian local government is not without some support. County-level government use in California and the Australian local government authorities sampled are, however, statistically different to use of the web in marketing made by Californian city government and Alabama county and city government use. It is suggested that further investigation is required to more fully understand the underlying reasons for such variance.

Journal of Database Marketing \& Customer Strategy Management (2007) 14, 297-310. doi:10.1057/palgrave.dbm.3250057

Stewart Adam Faculty of Business and Law Deakin University Melbourne VIC 3125, Australia

Tel: +6139244 6054; Fax: +6139251 7083; e-mails: stewart.adam@ deakin.edu.au; feather@ jsu.edu

\section{INTRODUCTION}

Arguably, use of the world wide web (web) is ubiquitous in developed countries. This use encroaches on most facets of life, including use in commercial transactions and not-for-profit exchanges. Our focus in this paper is not use of the web by individual 'clients' for whatever purpose but rather use of the web by government specifically, local government in the researchers' countries of domicile, that is, Australia and the United States of America. The reason is a simple one: 'government' is as all-pervasive as the web, and while much of the extant research either deals with extending citizen action and rights by way of the web, or is concerned with 'useability' in and of itself, there is no comparative examination of government's use of the web as a marketing tool. It was not possible to 
identify comparative studies of web use in marketing by local government, and this spurred us to action.

When comparing our cross-cultural experiences of local government, it became clear that, in most respects, local government is much like any for-profit or not-for-profit service provider. Citizens (customers) exchange money (taxes and fees) for products (services such as street cleaning, garbage collection, and disposal, even childcare), and in the process they receive varying degrees of value and form relationships of varying depth with their supplying government. While it is acknowledged that there is more to local government, this line of reasoning is used to illustrate the point that there is a marketing process involved in local government just as there is in business. ${ }^{1}$ Moreover, the range of products on offer is as extensive as any business, includes internally offered and outsourced services, and varies by local government type and locale (ie county, city, town, or local government area (LGA)), as well as within and between countries and states.

Hanson $^{2}$ proffered that business uses the web for productivity reasons and for market growth. The two uses are not mutually exclusive as an example illustrates: Online marketing companies enable their field salesforces, internal salesforces, and customers in far-flung markets to access electronically managed SKU (stock-keeping unit) inventory information via extranets and to order online. Each party is then advised in realtime that the products have been despatched and when receipt might be expected. And of course, the revised inventory information is also available electronically in realtime. At the outset, it was our contention that local governments' use of the web is little different and this spurred us to examine the matter in a systematic way.

The coverage of this empirical study commences with a review of the extant literature concerning online marketing, including newer developments in web use, particularly social networking. A review of the literature concerning government use of the web is also included and from which our research hypotheses are developed. Next, the methodology employed in systematically auditing local government websites in the two countries of interest is presented. The findings are discussed at length, and the paper concludes with a discussion on the implications for local government, together with suggested directions for future research. The limitations of the study are acknowledged, as is the manner in which future research might overcome these, as the paper is drawn to a close.

\section{USE OF THE WEB IN MARKETING}

While much attention is given to use of the web in marketing communication, a more inclusive view of the web is one that sees its most powerful use with subscribers and members, direct marketing if you will, wherein the marketing process is concentrated on three elements of marketing, viz., interactive marketing communication, marketing logistics (marketing channels in particular), and relationship management. ${ }^{3}$ While not intending to elaborate too greatly on each of these elements, it is necessary to comment further on their selection over other aspects of marketing. Earlier studies ascertained that business saw the web used in these three elemental roles. ${ }^{4,5}$ During development, interviews with business representatives ${ }^{6}$ and discussions with an international network-centric market intelligence firm concerning automation of the research tool were pivotal in the decision to retain this three-element perspective. The research tool employed in the present study is discussed further in the methodology section of the paper.

Prior to the present study, researchers had suggested that Australian federal and state 
government use of the web in marketing was more sophisticated than business use of the web, noting that at the time, government sites solely sought improvement gains, while business sites also seek market growth gains. ${ }^{7}$ The difference in sophistication of use might have been attributable to a slower start in such use by business in Australia. It is argued that now, government uses the web both to improve productivity and to stimulate market growth. Enabling tax and fee payment online is an example of a productivity gain for both government and citizenry, while streaming videos showing the delights of living in a particular locale, or the plentiful availability of employment, shows intent to grow their market.

The prompt to the researchers in the present study was to ascertain if the lead that government had previously shown in Australia was also evident in the birthplace of the internet, the United States, and while business use is not within the ambit of the present study, to ascertain at this later point in time whether government use has been extended. Certainly, the trend for local government to use the web was evident in the UK even in the early years, leading Horrocks and Hambley ${ }^{8}$ to observe that it really took a conscious decision for councils to stay off the web. Later, researchers in New Zealand noted that local government use of the web was developing, but that based on local government employee reports of included/missing features of local government websites, some further development was needed if citizens were to fully benefit. ${ }^{9}$ Our aim then is to examine the progress made by local government in its use of the web in marketing, by auditing host websites.

\section{THE ONLINE INTERACTIVE MARKETING COMMUNICATION ELEMENT}

There is evidence suggesting that expenditure on the web in marketing communication will soon overtake magazine advertising expenditure in developed countries such as Australia. ${ }^{10}$ In this particular country, combined government expenditure means that government is one of the biggest, if not the biggest, advertiser, depending on elections and issues. While classified advertising on the web has been strong for some time, thanks to the search function, what might be considered a more mainstream use - a display advertising approach - has come to the fore.

Nevertheless, this is but one element of marketing, albeit a highly visible one, that receives academic ${ }^{11}$ and commercial investigation.

Given the already alluded to heavy marketing communication expenditure by government, and given the relatively greater anticipated budgets for web development by government in the United States relative to Australia (given the population differences), not to mention that the internet was developed in the US, the following hypothesis was developed:

$\mathbf{H}_{1}$ : Local government use of the web for marketing communication in United States county and city websites evidences greater sophistication than local government in Australia.

\section{THE ONLINE MARKETING LOGISTICS ELEMENT}

An understanding of the second marketing element - marketing logistics — is a prerequisite to comprehending how a great deal of organisational performance is achieved in industry and government. In turbulent environments, faster response times are required, and adaptive organisation structures and management styles are also in evidence. ${ }^{12}$ This is particularly so in manufacturing organisations where producing to order rather than to inventory, even if only done notionally, is perhaps more critical than in service organisations such as 
local government. Customer perceptions of timeliness and accessibility, however, arise in each case, and for this reason, among others, the web's role in marketing has come to the fore.

Another point that arises in the marketing logistics context is the pressure to rethink business processes. Hagel III and Singer ${ }^{13}$ posited that 'beneath the surface of most companies, you find three kinds of businesses - a customer relationship business, a product innovation business, and an infrastructure business ... They each play a unique role; they each employ different types of people; and they each have different economic, competitive, and even cultural imperatives'. The point being made here has two implications. First,

organisational processes are being unbundled and placed with other network members, and secondly, that there is an increased need to coordinate member activities, which were once internal. This is little different in the case of local government, which now must also rely on infrastructure in the form of database use and the web, not only to reduce internal coordination costs and reduce distribution costs, but also to develop, maintain, and enhance relationships with householders and businesses that it might otherwise be tempted to dismiss as 'captive customers'. This is evidenced by allowing third parties such as Australia Post to facilitate online merchant services whereby taxes and licence fees may be paid online.

Layne and Lee ${ }^{14}$ observed that there are various stages in the development of what they termed fully functional e-government. The fourth and final stage they alluded to is the Horizontal Integration stage wherein administrative reform is achieved and a type of 'one stop shop' approach is in evidence. It is suggested that this is evidenced by the existence of such website features as an intranet (secure access for employees only) and/or extranet (secure access for citizens and employees) among other features that include online tax-paying. This led to the development of the following hypothesis:

$\mathbf{H}_{2}$ : Local government use of the web as a marketing channel in United States county and city websites evidences greater sophistication than local government in Australia.

\section{THE ONLINE RELATIONSHIP MANAGEMENT ELEMENT}

Turning to the third element of marketing involved in web use, we see that much has been made of the evolution of new paradigms and the emergence of customer relationships in the marketing discipline ${ }^{15,16}$ and in business information systems when referring to customer relationship management (CRM) in e-commerce. As Ang and Buttle ${ }^{17}$ point out, CRM is 'the core business strategy that integrates internal process and functions, and external networks, to create and deliver value to targeted customers, at a profit'. Arguably, this should equally be the case in government as it is in business, noting that as is the case with many studies, Ang and Buttle restricted their investigation to business use of CRM.

It is to be noted that the term e-commerce represents the transaction element of online marketing and electronic business. ${ }^{18}$ Aspects such as customer addressability through database use, ${ }^{19}$ interactivity, share of customer ${ }^{20}$ are among the more salient features when discussing the use of the web in online relationship management. It is suggested that this also applies in local government and is yet another reason why government employs the web.

Local government should be seeking to employ the web to satisfy customers completely. Jones and Sasser ${ }^{21}$ stated that typically, a completely satisfied customer believes that the supplier excels in understanding and addressing his or her 
personal preferences, values, needs, or problems. They suggest that for an organisation to identify how customers may be satisfied in this fashion, it must excel at listening to its customers and interpreting what they are saying. The marketing organisation should be aiming to develop completely satisfied customers who, in turn, become what Jones and Sasser described as 'Loyalists/Apostles' who, because they are so satisfied, share their views with others.

Given the head start that US business had in database use in direct marketing in particular, and the expectation that this would be evidenced in the local government arena, our third hypothesis developed:

$\mathbf{H}_{3}$ : Local government use of the web for customer (citizen) relationship management in United States county and city websites evidences greater sophistication than local government in Australia.

\section{THE MARKETING READINESS OF LOCAL GOVERNMENT WEBSITES}

Returning to the audit of websites, it is of note that while there may be differences in the degree of sophistication of use of the web in the three marketing elements, it is the overall Marketing Readiness of Website Indicator (MRWI) index evaluation that illustrates the level of web use in the marketing process by local government. Of interest is the extent to which early mover advantage by local government in the US translates into difference in the use made of the web relative to local government use in Australia. This led to development of the following hypothesis:

$\mathbf{H}_{4}$ : Local government use of the web in United States county and city websites evidences greater sophistication of overall marketing use than local government in Australia.

\section{COMPENDIUM OF INTERNET USE IN AUSTRALIA AND THE UNITED STATES}

As Table 1 indicates, there are similarities and differences in the population sizes of each of the six local government classifications examined. There are similarities in the state population of Alabama and Victoria and also in Gross State Product. The total population of the Californian cities sampled is similar to the populations of the aforementioned states. These comparisons, however, hide much in the way of demographic differences. With 35.2 per cent of the Californian population reported to be Hispanic and 12.2 per cent reported as Asian persons, it might be expected that local government websites in Californian counties and cities would cater to these cultural groups in terms of offering multilingual support. In the smaller state of Alabama, there are much smaller numbers by comparison -2.3 and 0.8 per cent, respectively. In the Australian state of NSW some 23.8 per cent were born overseas, with 2.0 per cent born in Vietnam and China. In Victoria, 23.8 per cent were born overseas, with 2.2 per cent of the population born in these two countries. In each of these Australian states only 74 per cent reported speaking English at home, leading to the expectation that there would be differences in the way local government catered to multicultural groups. ${ }^{22}$

Table 1 illustrates that internet penetration of households in Australia is high at 70 per cent and equally high at 65 per cent of a much larger population in California. In Australia, of the 4.7 million homes with internet access, 48 per cent had broadband access by 2006, that is, Digital Subscriber Line (DSL) or cable access. This equates to some 34 per cent of total households. Only 29 per cent of people aged 15 years or over access the internet from their workplace. ${ }^{23,24}$

Access to the internet in the United States is proportionally similar in that 59 
Table 1: Sampled websites by local government classification

\begin{tabular}{|c|c|}
\hline California counties & Alabama counties \\
\hline (CALCOUNT) sites $(n=30)$ & (ALBACOUNT) sites $(n=30)$ \\
\hline$N=58$ & $N=67$ (39 with websites) \\
\hline State population $(2005)=36,132,147$ & State population $(2005)=4,557,808$ \\
\hline Population of selected counties $=19,243,000$ & Population of selected counties $=2,423,000$ \\
\hline Gross State Product=US\$1,622,116 million & Gross State Product=US\$151,610 million \\
\hline State internet penetration $=65 \%$ of individuals & State internet penetration $=48 \%$ of individuals \\
\hline 18 years and over & 18 years and over. \\
\hline California cities & Alabama cities \\
\hline (CALCITY) sites $(n=30)$ & (ALBACITY) sites $(n=30)$ \\
\hline$N=478$ & $N=100$ (with websites) \\
\hline Population of selected cities $=4,513,000$ & Population of selected cities $=1,551,000$ \\
\hline NSW local government & Victorian local government (VICLGA) \\
\hline (NSWLGA) sites $(n=30)$ & sites $(n=30)$ \\
\hline$N=153$ & $N=78$ \\
\hline State population $(2004)=6,720,800$ & State population $(2004)=4,963,000$ \\
\hline Population of selected LGAs=1,782,000 & Population of selected LGAs $=1,493,000$ \\
\hline Gross State Product=US $\$ 255,633$ million & Gross State Product=US\$186,656 million \\
\hline Australia GDP=US\$772,775 million & Australia GDP=US\$772,775 million \\
\hline $\begin{array}{l}\text { Australian internet penetration=70\% or } 4.7 \text { million } \\
\text { households }\end{array}$ & $\begin{array}{l}\text { Australian internet penetration }=70 \% \text { or } 4.7 \text { million } \\
\text { households }\end{array}$ \\
\hline
\end{tabular}

Sources: DSRD, ${ }^{23}$ Pew, ${ }^{25}$ and Census and ABS. ${ }^{43-45}$

Notes: Exchange rate used to convert Australian dollars to US dollars $=0.80$.

per cent of the population 18 years of age and older accessed the internet from home by 2003 - or some 55 per cent of households, representing over 62 million households. It is notable that some 62 per cent of households in the West region accessed the internet at that time, which is somewhat higher than the 55 per cent reported for the Southern region. Given the lower penetration of the internet at some 48 per cent of the Alabama population, we might expect differences in the way local government in this state uses the internet relative to California - the other state where local government websites were examined. ${ }^{25,26}$ This lower-than-average internet use means that the state of Alabama ranks 43rd in terms of PC ownership and 44th in terms of internet access in the US, a situation that is being addressed in view of its influence on the state economy. ${ }^{27}$

Given that the study does not involve a contact research phase, it is only possible to state that these differences should be taken into account rather than speculate on how these differences influence local government use of the internet and web in their marketing effort.

\section{RESEARCH METHODOLOGY - MRWI AND WEBSITE SAMPLING}

In this section, two aspects of the methodology employed in the study of local government use of the web in marketing are discussed. The first is the MRWI and the second is the sampling method employed.

\section{MARKETING READINESS OF WEBSITE INDICATOR}

The methodology employed in the present study involved content analysis of local government websites in two states in the United States and two states in Australia. The content analysis tool used in this study, the MRWI, employs emergent coding that began with an audit of Australian and New Zealand websites and extended to a comparison of use of the web by UK companies. ${ }^{4}$ The initial content analysis tool was further developed following discussions with a network-centric market intelligence 
firm involved in data analysis of Internet Service Provider (ISP) cache data and ISP geo-demographic information. The MRWI has been used in various studies ${ }^{5}$ and is used commercially.

The MRWI employs content analysis, which is a commonly employed research technique across a variety of disciplines. ${ }^{28}$ The technique may broadly be described as 'any technique for making inferences by objectively and systematically identifying specified characteristics of messages'. ${ }^{29}$ Employing this definition permits extension of the technique from its origins of analysing text messages to analysis of television programmes, commercials, advertising generally, ${ }^{30}$ and indeed websites ${ }^{31-33}$ In the case of websites, it is recognised that while we can really only know why organisations use the web by asking them, we can ascertain how they use the web by observation.

Conducting a manual classification involves a researcher manually examining website content against a multi-attribute framework, including examination of the HTML source code. Statistical analysis is involved in quantitative studies such as the present study, where the content analysis phase was undertaken with 180 websites.

In essence, the MRWI entails evaluating websites in terms of the capability of the sites across three main elements of marketing, viz., interactive marketing communication capability, marketing logistics, or channel, capability, and relationship continuity capability. Fifty points are allocated across marketing communication items, which includes up to ten points for identification of 10 of the 14 Resnik and Stern ${ }^{30}$ information cues, viz., 'price, quality, performance, components or parts, availability, special offers, guarantees or warranties, safety, independent research, and company research'. While some useability indicators such as ALT statements

(ALTernative text statements associated with images), the use of META tags (used by
Search Engine spiders and robots), and suitability for the visually challenged (eg the third-party Wave 3.0 Web Accessibility Tool is employed to reduce subjectivity in this assessment) are included, the MRWI is not meant to be an indicator of website design per se. Rather, it is mainly used to assess marketing communication elements such as brand and URL association and logo prominence, in addition to the other aspects of marketing strategy elaborated on next.

Online marketing channel capability, e-commerce in the argot of the internet, does not simply involve transactions and the use of shopping carts on websites, for it also includes online payment of bills and coordinating the activities of channel members. ${ }^{34}$ Accordingly, 25 points are allocated across items such as the degrees of web use in order-processing. In addition, 25 points are allocated across a range of items for relationship continuity capability, for example, whether an extranet is provided for customers/members/subscribers. The total rating out of 100 indicates the marketing readiness of the websites concerned.

\section{SAMPLING LOCAL GOVERNMENT}

The unit of analysis in this study is the organisation's website. One hundred and fifty websites were analysed according to the classifications shown in Table 1. It was decided to analyse local government in the form of both county and city sites in the United States given that, arguably, neither are identical to Australian local government.

Californian county local government websites were randomly selected from the 58 county census available from the California State Association of Counties. ${ }^{35}$ The Californian city websites were randomly selected from the list of incorporated cities. Alabama counties were chosen from the census of 67 counties (39 with official websites) listed by the Alabama Department of Finance. ${ }^{36}$ Thirty Alabama cities with websites were also randomly 
selected from this source. Australian local government sites were chosen at random from the census of 78 Victorian LGAs and 153 NSW LGAs publicly available from the Australian Local Government Association. ${ }^{37}$ In each case, record numbers were assigned to the organisations in the lists and samples derived from random numbers generated in Microsoft Excel.

Thirty sites were randomly chosen for each category to meet the generally accepted minimum cell size when employing statistical tests such as independent samples $t$-test and analysis of variance (ANOVA) among other tests designed to detect differences between or among groups. It is suggested that 30 participants per cell leads to 80 per cent power or the ability to detect significant differences. ${ }^{38}$

In most instances, the MRWI relies on investigating word (eg information cues) and tool usage (eg secure online payments) by way of internal search of each site where a search mechanism was provided, and/or by using the following command line with Google — 'keyword site: www. sitebeing-searched.xxx'. The MRWI also relies on use of such publicly accessible computer-based tools as the previously mentioned Wave 3.0 Web Accessibility Tool as a means of increasing inter-rater reliability; in this case when assessing the degree to which the needs of the visually challenged are catered for in terms of the use of frames in web pages, ALT statements among other checks.

\section{FINDINGS AND DISCUSSION}

The discussion of the results commences with an examination of the summary presented in Table 2. As might have been expected based on the population size and economic performance, Californian counties exhibit a greater degree of sophistication in terms of their marketing capability than counties in Alabama. Palmer et al. ${ }^{7}$ observed that the 'Victorian State Government is one that has shown a firm commitment to online information and service provision' and it would appear from the findings in the present study that this commitment has migrated through to local government website capability. This claim is made in light of Victorian local government websites matching the marketing readiness of Californian county sites in overall terms. A similar result is evident on each of the marketing elements examined in this paper, and highlighted in Table 2, viz., Marketing communication capability, including separate examination of use of Resnik and Stern's ${ }^{30}$ information cues; Marketing channel capability, including use of online orderprocessing for citizen payment of taxes, fees, and fines; Relationship management continuity capability.

From analysis employing MANOVA, univariate homogeneity of variance across the six organisational groups is not evident in the case of web capability in marketing communication (Levene test 2.47, $p=0.04$ ), marketing channel use (Levene test 8.15, $p=0.00)$, relationship management use (Levene test 4.84, $p=0.0$ ), or the overall MRWI evaluation (Levene test 4.39, $p<0.01)$. A similar lack of univariate homogeneity was evident in the case of online order-processing across the groups (Levene test 8.40, $p=0.00$ ). Post hoc Tamhane T2 tests were employed in analysing the between-group differences in website capability in the three marketing roles and for the overall MRWI evaluation. Because homogeneity of variance was observed in the case of Resnik and Stern's ${ }^{30}$ information cues, a Scheffe test was employed in analysing group differences on this item (Levene test 0.86, $p>0.05$ ).

The findings presented in Table 2 indicate that CALCOUNT, CALCITY, VICLGA, and NSWLGA websites make similarly sophisticated use of the web for marketing communication purposes. They are significantly more sophisticated in this use than ALBACOUNT and ALBACITIES. Therefore, $\mathrm{H}_{1}$ is not fully supported. This is 
Table 2: Results of post hoc means tests

\begin{tabular}{|c|c|c|c|c|}
\hline $\begin{array}{l}\text { MRWI item } \\
\text { (CALCOUNT } \\
\text { actual/possible } \\
\text { rating) }^{1}\end{array}$ & Group $^{2}$ (Ratings) & Post hoc test & $\begin{array}{l}\text { CALCOUNT } \bar{X} \\
\text { difference from }_{\text {group }^{(1-2)}}\end{array}$ & Sig. \\
\hline $\begin{array}{l}\text { Resnik and Stern } \\
\text { information cues } \\
(7.93 / 10)\end{array}$ & $\begin{array}{l}\text { VICLGA }(7.67) \\
\text { NSWLGA }(7.80) \\
\text { CALCITY }(7.20) \\
\text { ALBACITY }(5.70) \\
\text { ALBACOUNT (3.73) }\end{array}$ & Scheffe & $\begin{array}{l}-0.27 \\
-0.13 \\
-0.73 \\
-2.23^{\star} \\
-4.20^{\star}\end{array}$ & $\begin{array}{l}\text { NS } \\
\text { NS } \\
\text { NS } \\
0.00 \\
0.00\end{array}$ \\
\hline $\begin{array}{l}\text { Marketing } \\
\text { communication } \\
\text { capability (subtotal } \\
37.30 / 50 \text { ) }\end{array}$ & $\begin{array}{l}\text { VICLGA }(39.83) \\
\text { NSWLGA }(36.43) \\
\text { CALCITY }(34.20) \\
\text { ALBACITY }(29.40) \\
\text { ALBACOUNT }(23.73)\end{array}$ & Tamhane T2 & $\begin{array}{r}2.90 \\
-0.87 \\
-3.10 \\
-7.90^{\star} \\
-13.57^{\star}\end{array}$ & $\begin{array}{l}\text { NS } \\
\text { NS } \\
\text { NS } \\
0.00 \\
0.00\end{array}$ \\
\hline $\begin{array}{l}\text { Online order- } \\
\text { processing }(4.20 / 5)\end{array}$ & $\begin{array}{l}\text { VICLGA }(4.73) \\
\text { NSWLGA }(3.07) \\
\text { ALBACITY (1.33) } \\
\text { CALCITY (1.43) } \\
\text { ALBACOUNT }(0.87)\end{array}$ & Tamhane T2 & $\begin{array}{c}0.53 \\
-1.13 \\
-2.87^{\star} \\
-2.77^{\star} \\
-3.33^{\star}\end{array}$ & $\begin{array}{l}\text { NS } \\
\text { NS } \\
0.00 \\
0.00 \\
0.00\end{array}$ \\
\hline $\begin{array}{l}\text { Marketing channel } \\
\text { capability (subtotal } \\
15.37 / 25 \text { ) }\end{array}$ & $\begin{array}{l}\text { VICLGA }(16.03) \\
\text { NSWLGA }(11.07) \\
\text { CALCITY }(7.20) \\
\text { ALBACITY }(6.53) \\
\text { ALBACOUNT }(5.40)\end{array}$ & Tamhane T2 & $\begin{array}{c}0.67 \\
-4.30 \\
-8.17^{\star} \\
-8.83^{\star} \\
-9.97^{\star}\end{array}$ & $\begin{array}{l}\text { NS } \\
\text { NS } \\
0.00 \\
0.00 \\
0.00\end{array}$ \\
\hline $\begin{array}{l}\text { Relationship } \\
\text { continuity capability } \\
\text { (subtotal } 13.87 / 25 \text { ) }\end{array}$ & $\begin{array}{l}\text { VICLGA }(14.80) \\
\text { NSWLGA }(12.83) \\
\text { CALCITY }(10.27) \\
\text { ALBACITY }(9.17) \\
\text { ALBACOUNT }(4.30)\end{array}$ & Tamhane T2 & $\begin{array}{r}0.93 \\
-1.03 \\
-3.60^{\star} \\
4.70^{\star} \\
-9.57^{\star}\end{array}$ & $\begin{array}{l}\text { NS } \\
\text { NS } \\
0.03 \\
0.00 \\
0.00\end{array}$ \\
\hline $\begin{array}{l}\text { MRWI rating (total } \\
66.53 / 100 \text { ) }\end{array}$ & $\begin{array}{l}\text { VICLGA }(70.67) \\
\text { NSWLGA }(60.33) \\
\text { CALCITY }(51.67) \\
\text { ALBACITY }(45.10) \\
\text { ALBACOUNT }(33.43)\end{array}$ & Tamhane T2 & $\begin{array}{r}4.13 \\
-6.20 \\
-14.87^{\star} \\
-21.43^{\star} \\
-33.10^{\star}\end{array}$ & $\begin{array}{l}\text { NS } \\
\text { NS } \\
0.00 \\
0.00 \\
0.00\end{array}$ \\
\hline
\end{tabular}

*The $\bar{X}$ difference (Column 1 score minus Column 2 score) is significant at the level shown.

because in most respects, Australian and US local governments make similar use of the web for marketing communication purposes, with the exception of Alabama counties and cities. This less-sophisticated marketing communication use of the web by local government in Alabama is evidenced in other aspects of web use for reasons that are commented upon separately later in this section.

Employing a post hoc Scheffe test indicated that a similar situation exists in the case of the presence of Resnik and Stern's ${ }^{30}$ information cues. Google in-site searches were employed when websites did not employ access to internal search from their websites to test for the presence of these cues. It was necessary to also search on different terminology in some instances, for example, using tax rates, fees, and fines as an indicator of price. For various reasons, the findings concerning use of the web in marketing communication are not altogether surprising. First, as KPMG ${ }^{39}$ and others ${ }^{31,40}$ have observed, marketing communication use came to the fore very early in the commercial use of the web (1994), and so all organisational types have 
had time to develop richness in their use of the web for marketing communication purposes.

Attention now turns to an examination of use of the web as a marketing channel. As Table 2 illustrates, post hoc Tamhane T2 tests were employed, indicating that in the case of marketing channel capability, the $\bar{X} s$ for CALCOUNT, VICLGA, and NSWLGA are similarly significantly higher than for CALCITY, ALBACOUNTY, and ALBACITY. Online order-processing (which includes paying taxes and fees) ratings in the range of $1-5$ are awarded depending on the security level and on how the order is taken: Online secure payment $=5$; Online, no security $=4$; Online form request (ie send form and the organisation contacts you in return) $=3$; Online form for $\mathrm{fax}=2$; Offline ordering details advised $=1$; and no such service provision rates zero. Surprisingly, there is no significant difference between the Californian county and the Victorian and NSW local government sites in terms of the provision of online order-processing facilities. While one might be tempted to put this down to the fact that some Alabama counties and cities do not levy taxes, it would be difficult to find any such local government authorities that do not impose fees and fines at all.

There is, however, a significant difference in the capabilities of the local government websites between the US states of California and Alabama, and between the local government websites in the Australian states of Victoria and NSW in terms of permitting bill paying. When one considers the ease with which a link to a third-party merchant services provider such as Australia Post's Bill EXPRESS ${ }^{\circledR}$ secure website can be effected, these differences are surprising. Most notable are the lower capabilities of Alabama county websites both in terms of enabling secure online transactions and/or payments and in terms of overall use of the web as a marketing channel. In effect, $\mathrm{H}_{2}$ is not supported in that Californian counties, Victorian and NSW local government exhibit similar use of the web as a marketing channel. The other US entities examined are significantly less likely to employ an online marketing channel.

While information systems/IT professionals make much of the ecommerce (transactions) side of the web, ${ }^{41}$ many marketers might retort that the more difficult aspect is to keep customers coming back to websites, that is, relationship continuity and enhancing the scope of said relationships. It is notable that once again there is a mixed picture of use of the web in relationship management evidenced by US and Australian local government. The Californian county and two groups of Australian local government websites offer significantly greater capabilities than Californian cities and Alabama county sites in this regard. California counties make similar use of the web in this context as Victorian and NSW local government, albeit that each has some way to go in this regard. At the city level though, the sampled Californian cities do not fully use the relationship management capabilities of the earlier entities. Yet again, Alabama counties under-utilise the web in terms of this online marketing function. In effect, $\mathrm{H}_{3}$ is not supported. This suggests that despite much commentary by marketing academics and practitioners concerning the organisational performance benefits associated with developing, maintaining, and enhancing the scope of relationships between buyers and sellers, ${ }^{42}$ local government in Californian cities, and Alabama counties and cities are yet to implement strategic use of the web in this regard.

Turning to the overall MRWI ratings shown in Table 2, it is clear that $\mathrm{H}_{4}$ is also not supported. Once again, Californian counties, Victorian, and NSW local government are significantly moresophisticated users of the web in 
Table 3: Regressions - MRWI and population by county, LGA and city

\begin{tabular}{|c|c|c|}
\hline $\begin{array}{l}\text { Local government } \\
\text { site }\end{array}$ & $\mathbf{F}$ & Sig. \\
\hline \multicolumn{3}{|c|}{ Online marketin a comm } \\
\hline CALCOUNT & 3.40 & NS \\
\hline CALCITY & 6.72 & 0.02 \\
\hline ALBACOUNT & 3.89 & NS \\
\hline ALBACITY & 6.58 & 0.02 \\
\hline VICLGA & 12.07 & 0.00 \\
\hline NSWLGA & 0.79 & NS \\
\hline \multicolumn{3}{|c|}{ Resnik \& Stern Info. Cues } \\
\hline CALCOUNT & 2.79 & NS \\
\hline CALCITY & 5.04 & 0.03 \\
\hline ALBACOUNT & 0.14 & NS \\
\hline ALBACITY & 0.78 & NS \\
\hline VICLGA & 11.66 & 0.00 \\
\hline NSWLGA & 0.51 & NS \\
\hline \multicolumn{3}{|c|}{ Online marketing channel } \\
\hline CALCOUNT & 3.44 & NS \\
\hline CALCITY & 11.38 & 0.02 \\
\hline ALBACOUNT & 18.74 & 0.00 \\
\hline ALBACITY & 8.51 & 0.01 \\
\hline VICLGA & 0.15 & NS \\
\hline NSWLGA & 5.58 & 0.03 \\
\hline \multicolumn{3}{|c|}{ Online order-processing } \\
\hline CALCOUNT & 2.76 & NS \\
\hline CALCITY & 10.05 & 0.00 \\
\hline ALBACOUNT & 11.37 & 0.00 \\
\hline ALBACITY & 8.85 & 0.01 \\
\hline VICLGA & 0.70 & NS \\
\hline NSWLGA & 6.36 & 0.02 \\
\hline \multicolumn{3}{|c|}{ Online relationship mangement } \\
\hline CALCOUNT & 3.59 & NS \\
\hline CALCITY & 8.55 & 0.01 \\
\hline ALBACOUNT & 6.10 & 0.02 \\
\hline ALBACITY & 5.12 & 0.03 \\
\hline VICLGA & 0.81 & NS \\
\hline NSWLGA & 2.98 & NS \\
\hline \multicolumn{3}{|l|}{ MRWI } \\
\hline CALCOUNT & 4.83 & 0.04 \\
\hline CALCITY & 11.41 & 0.00 \\
\hline ALBACOUNT & 10.91 & 0.00 \\
\hline ALBACITY & 16.24 & 0.00 \\
\hline VICLGA & 2.28 & NS \\
\hline NSWLGA & 5.27 & 0.03 \\
\hline
\end{tabular}

implementing their marketing strategies than are Californian city government and local government in Alabama counties and cities.

During the audit, a search was conducted on Alabama counties that were listed as not having official websites. It was found that one non-official Alabama county website had been 'parked' with a Domain Name registrar or the registrar had taken the liberty of registering the site and had populated it with links to county businesses, thereby monetising the site. We also noted that 15 seemingly official Alabama sites were not as they first appeared via a Google search, but rather that they were managed by RootsWeb and AllGenWeb genealogy members. These county sites were not audited.

It is reiterated here that there are many differences between the revenue sources and sizes of counties and cities in each US state and this is particularly evident when comparing California and Alabama. Using population size as a surrogate for revenue, we regressed the MRWI evaluations and elements against the population in each LGA in the study. While there is a mixed picture of associations between MRWI elements in the various areas and population size, overall MRWI evaluations are associated with population size in each case except for VICLGA, as Table 3 indicates. At the between-country level, the MRWI ratings, however, appear to be independent of GSP and population size.

The identified associations are not entirely unexpected given that like advertisers, marketing budget allocation tends to vary with the revenue and earnings of companies. The findings in this regard do, however, illustrate that there is perhaps a double-jeopardy effect in evidence. That is, the less-populated LGAs perhaps do little marketing at all and tend not to use the web in marketing, thereby achieving the MRWI ratings awarded. Victorian local government tends to be different in this regard, and without contact studies, the reasons are not immediately obvious.

\section{CONCLUSIONS AND IMPLICATIONS}

In closing the paper, focus turns to discussion on the academic and managerial implications of the findings of the present study, limitations of the study, and opportunities for further research. 
It is evident from this study that in many ways, local government use of the web in two Australian states is the equal of county use of the web in the most populous and economically vibrant state in the United States. Californian county government and local government in the two Australian states are equally sophisticated in their use of the web for marketing communication and in terms of online order-processing. Local government use of the web in the two countries, however, differs most in marketing channel and relationship management use. Alabama county and city government lag in their use of the web for these roles relative to the higher performing LGAs and relative to the audit ratings that could possibly be awarded.

From a managerial perspective, it would seem that the less-sophisticated local government users either do not make comparisons between their sites and those of sister local government to establish best practice and emulate it, or they are less able to devote funds to the development of their sites. Earlier in the paper, it was noted that we can observe how local government and others use the web, but that we need to delve further via interviews or surveys in order to get behind the reasons for such use. Future contact research is paramount if the full explanation for the variance between local government websites is to be known.

From our unpublished investigations, and anecdotal evidence, we know that various industries tend to adopt a similar look and feel in their websites. ${ }^{3}$ One reason for this is the fact that users of one industry site are quite likely to move straight to another same industry site, for example, when undertaking comparison shopping for airline tickets. Alternatively, they may do so via a favoured search engine (eg Google or Yahoo!) or portal (eg NineMSN.com.au). Perhaps local government officials feel that their patrons are sequestered from patrons in other LGAs - in effect a captive market - and they therefore do not need to examine other local government websites. Herein lies a major weakness of the present study in that further studies are needed if we are to state with more certainty the underlying reasons for the statistical differences in local government use of the web between the two countries involved and between all levels of government. It might be argued that there is no likelihood of websites in different locales ever being similar in their use of the web in marketing. The authors aim to remedy this in time, and encourage others to investigate the matter further.

\section{Acknowledgments}

We thank Fitzgerald Marketing Group for providing MRWI second auditor assistance with the Australian local government websites.

\section{References}

1 AMA (2004) 'AMA adopts new marketing definition', American Marketing Association. Available from http://www.marketingpower.com/ content21257.php, accessed 30th November, 2006.

2 Hanson, W. (2000) 'Principles of internet marketing', South-Western College Publishing, Cincinnati, $\mathrm{OH}$.

3 Adam, S. (2002) 'A model of web use in direct and online marketing', EM: Journal of Electronic Markets and Business Media, Vol. 12, No. 4, pp. 262-269.

4 Adam, S., Mulye, R., Deans, K. R. and Palihawadana, D. (2002) 'E-marketing in perspective: A three country comparison of business use of the internet', Marketing Intelligence and Planning, Vol. 20, No. 4, pp. 243-251.

5 Adam, S. (2004) 'The role of the web in marketing and organisational performance', unpublished Doctoral dissertation, Deakin University.

6 Adam, S. (2001) 'One-to-one e-marketing strategy alignment: Five internet case studies', paper presented at Proceedings of the Academy of Marketing Annual Conference, Cardiff, Wales, UK.

7 Palmer, D., Adam, S. and Deans, K. R. (2000) 'Victorian.Government@online: Emarketing strategy in review', paper presented at Proceedings of the Australian and New Zealand Marketing Academy Conference, Gold Coast.

8 Horrocks, I. and Hambly, N. (1998) 'The 'webbing' of British local government', Public Money $\mathcal{E}$ Management, Vol. 18, No. 2, pp. 39-44. 
9 Deakins, E. and Dillon, S. M. (2002) 'E-government in New Zealand: The local authority perspective', International Journal of Public Sector Management, Vol. 15, No. 5, pp. 375-398.

10 C.E.A.S.A. (2006) '30 seconds', Australian Financial Review, Marketing and Media, 1 May, p. 52.

11 Hofacker, C. F. and Murphy, J. (1998) 'World Wide Web banner advertisement copy testing', European Journal of Marketing, Vol. 32, No. 7/8, pp. 703-712.

12 Achrol, R. S. (1991) 'Evolution of the marketing organization: New forms for turbulent environments', Journal of Marketing, Vol. 55, October, pp. $77-93$.

13 Hagel III, J. and Singer, M. (1999) 'Unbundling the corporation', Harvard Business Review, Vol. 77, No. 2, pp. 133-141.

14 Layne, K. and Lee, J. (2001) 'Developing fully functional e-government: A four stage model', Government Information Quarterly, Vol. 18, pp. 122-136.

15 Grönroos, C. (1994) 'From marketing mix to relationship marketing: Towards a paradigm shift in marketing', Management Decision, Vol. 32, pp. 4-20.

16 Brodie, R. J., Coviello, N. E., Brookes, R. W. and Little, V. (1997) 'Towards a paradigm shift in marketing? An examination of current marketing practices', Journal of Marketing Management, Vol. 13, pp. 383-406.

17 Ang, L. and Buttle, F. (2006) 'CRM software applications and business performance', Database Marketing \& Customer Strategy Management, Vol. 14, No. 1, pp. 4-16.

18 Turban, E., King, D., Lee, J., Warkentin, M. and Chung, H. M. (2002) 'Electronic commerce: A managerial perspective', Prentice-Hall, Upper Saddle River, NJ.

19 Blattberg, R. C. and Deighton, J. (1991) 'Interactive marketing: Exploiting the age of addressability', Sloan Management Review, Vol. 33, No. 1, pp. 5-14.

20 Peppers, D. and Rogers, M. (1995) 'A new marketing paradigm: Share of customer, not market share', Managing Service Quality, Vol. 5, No. 3, pp. $48-51$.

21 Jones, T. O. and Sasser Jr, E. (1995) 'Why satisfied customers defect', Harvard Business Review, Vol. 73, No. 6, pp. 88-91.

22 ABS (2007) 'Census quickfacts'. Australian Bureau of Statistics. Available from http://www.censusdata.abs. gov.au/, accessed 19th July, 2007.

23 DSRD (2007) 'Internet users - International 2006' NSW Department of State and Regional Development. Available from http://admin.business. nsw.gov.au/PDF/infrastructure-D10_internetusers_ intl.pdf, accessed 19th July, 2007.

24 ABS (2006) '8146.0 - Household use of information technology, Australia, 2005-06'. Australian Bureau of Statistics. Available from http:// www.abs.gov.au/Ausstats/abs@.nsf/0/acc2d18cc958b c7bca2568a9001393ae?OpenDocument, accessed 20th July, 2007.
25 Pew (2003) 'Both coasts lead the nation in internet use'. Pew Internet \& American Life Project. Available from http://www.pewinternet.org/ $\mathrm{PPF} / \mathrm{r} / 65 /$ press_release.asp, accessed 19th July, 2007.

26 Cheeseman Day, J., Janus, A. and Davis, J. (2005) 'Computer and internet use in the United States: 2003'. US Census Bureau. Available from http:// www.census.gov/prod/2005pubs/p23-208.pdf, accessed 20th July, 2007.

27 SADF (2007) 'Broader access to broadband?', State of Alabama Department of Finance. Available from http://finance.alabama.gov/content/Detail_View. aspx?ID=131, accessed 20th July, 2007.

28 Kassarjian, H. H. (1977) 'Content analysis in consumer research', The Journal of Consumer Research, Vol. 4, No. 1, pp. 8-18.

29 Holsti, O. R. (1969) 'Content analysis for the social sciences and humanities', Addison-Wesley, Reading, MA.

30 Resnik, A. and Stern, B. L. (1977) 'An analysis of information content in television advertising', Journal of Marketing, Vol. 41, No. 1, pp. 50-53.

31 Adam, S. and Deans, K. R. (2000) 'Online business in Australia and New Zealand: Crossing a chasm', paper presented at Proceedings of AUSWEB 2K: The Sixth Australian World Wide Web Conference, Cairns, Australia.

32 van der Merwe, R. and Bekker, J. (2003) ‘ A framework and methodology for evaluating e-commerce web sites', Internet Research: Electronic Networking Applications and Policy, Vol. 13, No. 5, pp. 330-341.

33 Bauer, C. and Scharl, A. (2000) 'Quantitative evaluation of website content and structure', Internet Research: Electronic Networking Applications and Policy, Vol. 10, No. 1, pp. 31-43.

34 Steinfield, C., Kraut, R. E. and Plummer, A. (1995) 'The impact of interorganizational networks on buyer-seller relationships'. Available from http:// jcmc.indiana.edu/vol1/issue3/vol1no3.html, accessed 2nd February, 2007.

35 CCW (2007) 'California counties' websites'. California State Association of Counties. Available from http://www.csac.counties.org/default.asp?id=7, accessed 29th March, 2007.

36 ADF (2007) 'The Alabama directory'. Alabama Department of Finance. Available from http://www. info.alabama.gov/directory_county.aspx, accessed 28th May, 2007.

37 NAC (2007) 'National association of counties'. Available from http://www.naco.org/, accessed 28th March, 2007.

38 Cohen, J. (1988) 'Statistical power analysis for the behavioral sciences', 2nd Edition, Erlbaum, Hillsdale, NJ.

39 KPMG (1999) 'Electronic commerce: The future is here!', Nolan Norton Institute, Melbourne.

40 Poon, S. and Swatman, P. M. C. (1997) 'Internetbased small business communication: Seven Australian cases', Electronic Markets, Vol. 7 , pp. 15-21. 
41 Turban, E., Lee, J., King, D. and Chung, H. M. (2000) 'Electronic commerce: A managerial perspective', Prentice-Hall, Upper Saddle River, NJ.

42 Selnes, F. (1998) 'Antecedents and consequences of trust and satisfaction in buyer-seller relationships', European Journal of Marketing, Vol. 32, pp. 305-322.

43 Census (2005) 'State and county quick facts'. US Census Bureau. Available from http://quickfacts. census.gov/qfd/states/00000.html, accessed 21st May, 2007.
44 ABS (2006) 'Population projections, Australia, 2004 to 2101'. Australian Bureau of Statistics. Available from http://www.abs.gov.au/ausstats/abs@.nsf/ ProductsbyCatalogue/5A9C0859C5F50C30CA25718 C0015182F?OpenDocument, accessed 21st April, 2007.

45 ABS (2006) 'State accounts, 2005-06'. Australian Bureau of Statistics. Available from http://www. business.nsw.gov.au/aboutnsw/climate/gross_state_ product.htm, accessed 27th April, 2007. 